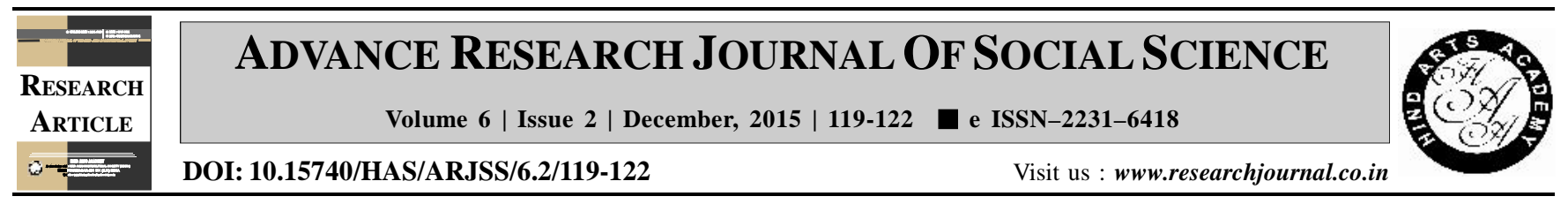

\title{
Socio-personal factors affecting parental perception towards contribution of non-resident Indian children
}

I. Kaur* and S. Thind

Department of Human Development, College of Home Science, Punjab Agricultural University, LUDHIANA (PUNJAB) INDIA (Email: best_ish85@yahoo.com)

\section{ARTICLE INFO :}

Received

Revised

21.03.2015

Accepted

: 05.10 .2015

: 19.10 .2015

KEY WORdS :

Perception, Non resident Indian children

\section{HOW TO CITE THIS ARTICLE :}

Kaur, I. and Thind, S. (2015). Sociopersonal factors affecting parental perception towards contribution of nonresident Indian children. Adv. Res. J. Soc. Sci., 6 (2) : 119-122.

*Author for correspondence

\begin{abstract}
A study was planned to see the effect of topic socio-personal factors affecting parental perception with respect to contribution of non-resident Indian Children. The sample of 200 parents were drawn from 150 families for which, 28 villages were covered to finalize the sample. The findings revealed that maximum numbers of parents were middle passed, whose children had migrated to overseas. As education of parents increased, less number of children had migrated to overseas. Maximum number of children had migrated from Jat families and minimum from Khatri families. Maximum number of children had migrated from families having small land holding $(<5)$ ha.
\end{abstract}

